\title{
MAURITIUS: THE NOT SO PERFECT DEMOCRACY
}

\author{
Roukaya Kasenally \\ Dr Roukaya Kasenally is Senior Lecturer, Media and Political Systems, Faculty of \\ Social Sciences and Humanities, University of Mauritius \\ e-mail: roukaya@uom.ac.mu
}

\begin{abstract}
Mauritius has come a long way since independence in 1968, when observers predicted that the 'overcrowded barracoon', as V S Naipaul referred to the island, would fail to achieve peace and economic prosperity. As a result of its success in managing diversity and capitalising on protected markets and guaranteed export prices Mauritius has emerged in recent decades as a democratic and economic model for its peers on the African continent. However, with the onset of globalisation Mauritius is now entering a period of democratic stagnation as islanders confront the rise of ethnic and dynastic politics, the advent of political cronyism and patronage, the marginalisation of minorities, and growing disenchantment with and cynicism about the political class. This article highlights what can be considered the numerous deficiencies and flaws in the highly celebrated Mauritian 'picture perfect model'. Due attention must be given to addressing these if a social, economic and political implosion is to be avoided.
\end{abstract}

\section{INTRODUCTION}

It is hard to find any literature or indicators ${ }^{1}$ that do not commend Mauritius on its economic performance and political stability. There is no doubt that the island

1 Economic indicators: Upper-middle-income economy, GDP per capita, US \$8 588 (World Bank indicators 2010); growth rate, 2.1\% (World Bank 2010); Index of Economic Freedom, 75,ranked $12^{\text {th }}$ worldwide (Heritage Foundation / Wall Street Journal 2010); Human Development Index .701, ranked $72^{\text {nd }}$ worldwide (UNDP 2010).

Democratic indicators: PR, 1; CL, 2, free (Freedom House 2011); Democracy Index 2010, full democracy (EIU); 83, $1^{\text {st }}$ in Africa (Ibrahim Index of African Governance 2010); Corruption Index, 5.4, ranked $39^{\text {th }}$ worldwide (Transparency International 2010). 
has fared well, despite being small, isolated and resource-poor. Many believe that it is the suave management of diversity and plurality, the setting up of key and independent institutions and the adoption of a ballot (instead of a bullet) culture that moved the island away from the problems that plagued a number of African countries as they became independent.

Mauritius is known for its cosmopolitanism and conviviality, which are marketed as important traits of the islanders and have served well in making the island a popular tourist destination and an investment hub for new businesses.

Situated in the warm waters of the Indian Ocean, east of Southern Africa, the Republic of Mauritius consists of Mauritius, Rodrigues and two smaller atolls (Agalega and Saint Brandon). It also had territorial control of the Chagos Archipelago, but this group of islands was excised by Britain in 1965 prior to independence. Mauritius is still trying to regain sovereignty over the Chagos Archipelago, including Diego Garcia, which has become an important military base for the United States.

Despite its geographical proximity to Africa, Mauritius is not a typical African country. The island has no indigenous population and essentially comprises people of immigrant origin, making it an ethnically diverse, linguistically rich and culturally vibrant society. The fact that the island has no native population and that no single ethnic group can claim a total majority partly explains the 'Mauritian miracle'. This concept is essentially an economic one, but it has been important in maintaining social harmony and political stability on the island.

Mauritius is defined by its Constitution as a secular country, but ethnoreligious markers are strongly at play, made visible by the different communities - Hindus (52\%), Creoles of African ancestry (27\%), Muslims (16\%), Chinese (3\%) and those of French/ British descent $(2 \%){ }^{2}$

The main argument of this article is that there is a much more nuanced reading and interpretation of the Mauritian democratic model than conventional writings and ratings report upon. A number of what can be termed worrying tendencies have been noted in the past decade or so and they already constitute a real danger to Mauritian pluralism, diversity and equity. Therefore, in highlighting the numerous flaws and deficiencies of the present state of democracy on the island one expects to demonstrate that Mauritian exceptionalism is not only a rather overrated notion it has, in fact, been the source of complacency and inaction among the island's political leaders, who continue to pretend that all is fine in paradise.

2 This ethnic classification dates back to the 1972 Census, which was the last time the Mauritian people were asked to define themselves in ethnic terms. 


\section{PARADIGM SHIFT IN THE MEANING AND UNDERSTANDING OF DEMOCRACY: THE CONSOLIDATION OF DEMOCRACY}

Democracy is a contested, multidimensional and dynamic term. Over the decades a long-running debate has pitted what might be called the 'preconditionists' against the 'universalists' (Berman 2010). The former believe that democracy generally emerges from a particular set of conditions and experiences, while the latter claim that it can come about in all sorts of ways and settings.

The universalist approach was given a real boost by the third wave of global democratisation that began in the mid-1970s and laid greater emphasis on the process of democratic transition and less on the structures supposedly associated with successful democracy. This, in turn, inaugurated an era when democracy was promoted as an important feature of Western foreign policy. By the 1990s there were a number of impressive democratic gains, as evidenced by the sheer number of countries which qualified to be called democracies. Unfortunately there now seems have been a reversal of fortunes and the world appears to be entering a democratic recession (Diamond 2008; Puddington 2011).

In light of this, the advent of democracy remains an elusive concept and there is a need to find a less generalist/blanket term, one that offers greater precision in meaning and understanding. What is required is to assess and evaluate democracy more meaningfully and tangibly, using a less supply-side approach (looking at institutions) and a greater demand-side one (looking at citizens). The work of Diamond \& Morlino (2005, p xi) offers an interesting take on a more substantive aspect of democracy by emphasising its quality: '... it provides its citizens a high degree of freedom, political equality, and popular control over public policies and policy makers through the legitimate and lawful functioning of stable institutions'. Diamond \& Morlino (2005) identify eight dimensions, namely, the rule of law, participation, competition, vertical accountability, horizontal accountability, freedom, equality and responsiveness. The eight categories are interconnected and, at first reading, seem to be rather obvious. However, what is important is the manner in which they are understood and owned by the people - the demand-side democracy mentioned above. Of particular relevance to what one may call a more people oriented democracy are participation, vertical accountability, competition and responsiveness, features that have a certain resonance in countries and societies which believe they have successfully achieved democracy.

\section{Participation through accountability and mobilisation}

One of the fundamental features of any democracy is that all its citizens have a formal right to political participation, including the right to vote. Political 
participation is further enhanced when the right to vote is coupled with the right to join political parties, shape the public agenda, communicate with and demand accountability from elected representatives and monitor their conduct. In fact, a high level of apathy among citizens in a number of established democracies has been noted, as many of them doubt the efficiency of democratic mechanisms to serve or represent them. However, with the arrival of the recent 'Arab Spring' the power of popular participation is back, with the capacity to uproot even the most entrenched authoritarian regime.

\section{Open and varied competition}

Democracies vary in their degree of competitiveness. Usually the most common and celebrated feature of political competition is the holding of regular, free and fair elections. No doubt this is a crucial feature, but a democracy must also be assessed in terms of its electoral model, equality of access to the mass media, financing of political parties and how open and inclusive it is of minorities (women and youth).

\section{Responsiveness}

Trust in democracy hinges to a great extent on the responsiveness of government to the expectations, interests, needs and demands of its citizens. Responsiveness depends very much on a proactive and engaged citizenry able to articulate and unite strongly in its demands and expectations.

More recently, the democratic assessment literature has expressed a growing concern about merely relying on a single-point score assigned to a particular country at a particular time and expecting the score to capture accurately all the nuances of democracy and be empirically valid through time. This concern has brought to centre stage the idea of disaggregated data about democracy. In 2008 the Committee on the Evaluation of USAID Democracy Assistance wrote (p 89):

No aggregate democracy index offers a satisfactory scale for purposes of country assessment or for answering general questions pertaining to democracy. Thus, the committee strongly supports USAID's inclination to focus its efforts on a more disaggregated set of indicators as a way of capturing the diverse components of this key concept while overcoming difficulties inherent in measures that attempt to summarize, in a single statistic, a country's level of democracy (à la Freedom House or Polity). 
Bratton (2010) makes a further case for the use of disaggregated democracy, which allows for a more bottom-up approach and develops a greater interest in understanding the more tangible attributes of a democratic regime. In fact, the most recent Afrobarometer round (Round 4) has made use of hypothetical democracy vignettes to develop deeper meaning for the term (Little \& Logan 2009).

\section{DEMOCRATIC DEFICIENCIES AND FLAWS IN THE MAURITIAN MODEL}

In 2004 a report entitled 'Competitiveness Report: What Orientations for Mauritius', prepared by the National Productivity and Competition Council (NPCC), highlighted the following:

To arrive at a shared vision for Mauritius, it is imperative that everybody should be able to voice his/her opinion without fear on the problems and future perspectives of Mauritius. Does this culture of open and constructive debate exist when the political competition model is based on patronage and clientelism? Or has such an open political culture, so essential for the conduct of a properly functioning democracy, been diminished by a climate of implicit fear that speaking one's mind will result in punitive sanctions of one sort or another?'

This statement reflects some of the underlying tensions, limitations and challenges in the practice of democracy on the island and this section attempts to shed some light on certain worrying features of the Mauritian democratic model.

\section{The rise of ethno-religious politics}

Mauritian politics is multifaceted to the point of being paradoxical. At one level it promotes a very broad-based approach to ensuring that all ethnic groups are included in what are termed 'rainbow-nation alliances'. Concurrently it also encourages ethno-religious politics, where appeals are made to groups to support those of their kind (Kadima \& Kasenally 2006).

Ethno-religious politics has its roots in pre-independence Mauritius. As the island negotiated its independence a sizeable percentage (44\%) of a population essentially made up of people of African and French ancestry voted against it, preferring to remain a British colony, an attitude motivated largely by the fact that they feared the Hindu community would monopolise power. 
Originally considered a single group, Indo-Mauritians subsequently began to classify themselves as Muslims, Tamils, or Hindus - with the last distinguishing themselves further by caste. In its early days (especially at the time of independence) ethno-religious politics was seen as a form of consociationalism (Srebrnik 2002; Jahangeer-Chojoo 2010). Unfortunately, in the past four decades ethno-religious politics has transformed itself from a relatively benign to a more insidious process, with grave ramifications for social harmony and diversity on the island.

Elections offer a particularly potent opportunity for ethno-religious strategies, with candidates chosen more for their ethnic coefficient than their intellectual capacity. This is an extremely worrying trend as it tends to favour a breed of politician who is myopic in his or her understanding and practice of the politics of diversity. Another worrying trend is the ascent within the Mauritian political landscape of purely ethnically driven parties that are aggressive and nonconsensual in their claims.

Mention was made above of the fear among certain communities of the growing influence of the Hindu community when the island attained independence. Today this fear is a reality as Hindus exercise considerable control and influence in a number of spheres.

Since independence every prime minister save one has been a Hindu of Bihari descent from the Vaish caste. Informally, many in the Hindu community take it as their right that the premier must be one of their own. This 'right' was most vociferously claimed in 2003 when, in terms of a pre-electoral agreement, the position was split between a Hindu (Aneerood Jugnauth) and a Franco-Mauritian (Paul Berenger). In fact, 2003 was a watershed year for ethno-religious politics, causing a rift in inter-ethnic relationships and allowing ethnically motivated groups to spring up.

\section{Dynastic, ailing and closed political parties}

Genuine political renewal does not seem to be part of the agenda of Mauritian political leaders. In 40 years of independence prime ministers have come from only two families - Ramgoolam or Jugnauth. The current prime minister, Navin Ramgoolam, son of the first prime minister (Sir Seewasgar Ramgoolam), is in his third term and has declared publicly that he is ready to carry on for the next 15 years (The Independent Daily, 21 April 2011).

Bunwaree \& Kasenally (2005) highlight the well-established internal structure of mainstream political parties as reflected by the committees that deal with matters pertaining to policy conceptualisation and decision-making. Despite political parties' investment in a decentralised framework the ultimate decisions 
on important matters concerning the party essentially lie with the leader and a very small caucus of party members.

This 'autocratic' approach to party leadership is never really contested, as the rank and file of party members are 'encouraged' to 'toe the party line' and avoid 'embarrassing' their leader in any circumstances. In fact, this 'toe or go' philosophy has, over the years, considerably fortified the unequivocal authority of the leader.

Closely linked to autocratic political leadership is the issue of political succession. There is a total absence of succession planning and this state of affairs does not augur well for democracy within political parties. The lack of opportunity to rise to the higher echelons of the party frustrates the more able and worthy candidates, who have to face an old political guard which retains most of the party privileges: renewed nominations and ministerial portfolios (when its party is in power).

\section{Stalled electoral reform}

In 2000 the Mauritian government commissioned a South African Constitutional Court judge, Albie Sachs, to look into the issue of electoral and constitutional reform. The terms of reference of the commission were articulated around the need for fairness, representation and accountability within the existing electoral and constitutional framework.

In 2002 the Sachs Report was made public. It made a series of recommendations which included introducing proportional representation, increasing the number of female candidates nominated, creating a structure for funding political parties and enhancing the powers and responsibilities of the electoral commission. In 2002 the government created a select committee to evaluate the recommendations of the report and offer a modus operandi for its implementation. Unfortunately, the members of the committee were split over their support for one electoral formula and, at the time of writing, the matter has still not been resolved.

Although there appears to be some consensus among the various political stakeholders, to date no real action has been taken. Mauritian civil society, through a number of initiatives, has pushed for the implementation of certain recommendations of the Sachs Report.

Transparency Mauritius (affiliated to Transparency International) ran a number of information campaigns to persuade political parties and corporate bodies to be more transparent and accountable in their funding and financing and the Institute of Social Development and Peace (ISDP, a Mauritian advocacy think-tank) has been active in persuading political stakeholders to commit to 
electoral reform through a series of dialogue sessions. ${ }^{3}$ Perhaps the group that has been (and continues to be) most vocal and visible in its demands is Reziztanz Ek Alternativ, which has challenged what it terms the 'unconstitutionality' of the 'best loser system' (BLS).

The BLS is an ethnic quota system that was devised at independence to ensure representation for all ethno-communual groups and was attached to the prevailing first-past-the-post electoral system. It was hailed by some as a means of ensuring the rights of underrepresented communities and therefore maintaining a pluri-ethnic Mauritius, but decried by others on the basis that it has, in fact, institutionalised communalism as it splits Mauritian society into distinct ethnic groups vying for their own self-interest and thus hampering the development of a truly Mauritian nation.

In terms of the system eight seats (in addition to the 62 occupied by elected members) were designated for the communal groups that were mostly underrepresented. Reziztanz EK Alternativ has written officially to the UN Human Rights Commission requesting that it take a stand on the matter and, more recently, has petitioned the Privy Council - the case is due to be heard in October 2011. Meanwhile, the BLS remains an ultra-sensitive issue that no political leader or party dares address for fear of losing the support of the more vocal members of these ethnic groups.

\section{Misunderstanding the idea of representation: the continued absence of women from politics}

Mauritius continues to be among the poorest performers when it comes to the political representation of women, despite the fact that the island is a signatory to the SADC Gender Protocol and the Convention on the Elimination of all Forms of Discrimination against Women.

The Sachs Report highlighted the fact that the underrepresentation of women in the country constitutes a 'grave democratic deficient'. Bunwaree (2010), in an in-depth analysis of the interplay among gender, governance and politics, sheds important light on the entrenched system of patriarchy as well on other structural and legal failings that perpetuate the underrepresentation of women in politics.

For instance, discussions about using a quota system to correct certain disparities and discrimination have been branded unconstitutional as they are believed to contravene the basic precepts of the Mauritian Constitution, which protects Mauritians against any form of discrimination in terms of creed, colour,

3 In 2006 the ISDP, with support from EISA and International IDEA, organised a session on the theme, 'Electoral Reform - Moving Towards An Inclusive Democracy'. This was followed, in 2009, by a second session, entitled 'Striving for a New Political Culture in Mauritius'. 
sex or race. However, judging by various experiences in Africa and Latin America, the quota system, when applied, has boosted the presence and presentation of women (Ballington 2004; Ballington \& Karam 2005).

Another mechanism that has been used extensively by women's movements to ensure greater solidarity and to push for a pro-women agenda is the women's caucus. Indeed, the development of a women's caucus has been strategic not only in getting more women into the legislature but also in extending their influence in a number of realms, among them, acting as a catalyst on key issues, acting as a watchdog on other issues and even becoming spokespeople on issues they wish to champion.

According to Thomas (1994) 'women who are organised in a caucus can serve the same purpose as a critical mass of women, even where women do not make up a significant portion of the legislature'. A number of African countries are leading the way and have developed interesting 'coalitions' headed by women parliamentarians. Mauritius has a lot to learn from these African countries, which are rapidly developing a class of women champions in politics who are increasingly challenging male dominated party structures.

\section{Strong executives, weak legislators}

Barkan (2009) emphasises the importance of a developed and powerful legislature, maintaining that there can be no democratic consolidation without one. He attributes a number of functions and responsibilities to legislators, among them, to pass laws that represent the varied and sometimes conflicting interests of society as a whole, to exercise oversight and to engage in constituency service.

Mauritius, unlike many African countries which have adopted presidential systems, has retained the Westminster parliamentary system it inherited at independence. The Constitution guarantees the separation of the powers of the executive, the legislature and the judiciary. It is interesting to note that Mauritius scores .66 on the Parliamentary Power Index (Fish \& Kroening 2009). ${ }^{4}$ This relatively high score demonstrates that the Mauritian legislature possesses most of the features of a functioning legislature, but the question that should be posed is: how effective is it in carrying out its various functions, as outlined in the work of Barkan (2009)?

Mauritius's legislature follows a well-established procedure according to the 'standing orders and rules of the National Assembly' (1995), with all the necessary administrative and procedural mechanisms of a well oiled machine,

4 The PPI, developed by Fish \& Kroening, is constructed by determining how many of 32 pre-established features a given legislature has. From this, the percentage of affirmative answers is computed. Scores range from .00 to 1.00 (the higher the score, the more powerful the legislature). 
including the various sessional committees (selection, public accounts, standing orders and the house), select committees and the types of questions asked (private notice questions and questions to ministers, among others). However, observation of successive parliaments has revealed a gradual weakening of the legislature, particularly in its role and responsibility in exercising oversight, especially over the executive. Barkan (2009, p 25) defines 'parliamentary oversight as the core relations between the legislature and the executive and, at the same time, ... one of the basic components of the theoretical and constitutional foundations of Parliament'.

Over the years the executive has grown stronger, with an increase in the number of ministerial portfolios ${ }^{5}$ and the creation of a parliamentary private secretary (PPS), which is equivalent to a junior ministerial position. Currently, the ruling coalition, headed by the Labour Party, has 45 elected members of Parliament, of whom 35 hold executive posts ( 25 ministers and 10 PPSs). A simple mathematical exercise indicates that well under 30 per cent of the ruling coalition are backbenchers, making it very difficult for them to exercise due oversight. In fact, legislative oversight in the current Parliament has essentially become the sole responsibility of the opposition, which numbers $22 \mathrm{MPs}$.

The second observation relates to the process of legislation, most of which is initiated, managed and controlled by the executive. It is extremely rare to see the legislature initiate or propose any type of legislation. Barkan (2009), in his extended study of African legislatures, writes about the importance of reformers who can push for the 'coalition of change' with a given legislature. Reformers, he believes, are a core group willing to lead their fellow members to adopt change: push for new laws, strengthen oversight and develop cross party alliances, among other things. In such circumstances the modus operandi of the reformer is to emphasise the idea of parity among members of the legislature and not to follow party allegiances blindly.

There has been very little research into the Mauritian legislature and no doubt such work would help shed important light on the means and mechanisms of helping it to become a space where democratic traditions are observed and practised.

\section{The rise of soft authoritarianism}

Authoritarianism settles in when there are very few, or no checks and balances. Often it is a direct consequence of leaders who are self-elected and, in the

5 Following the 2010 general election the Cabinet was increased from 18 to 25. This was done to accommodate the different coalition parties and to ensure ministerial positions. 
process, control most of the power levers. Above I have referred to the dynastic, ailing and closed culture that typifies Mauritian politics. Soft authoritarianism is essentially linked to the deteriorating relationship between the current prime minister, Navin Ramgoolam, and a section of the print media, more specifically La Sentinelle Group, considered to be one of the most influential media groups in the country.

Since 2006 there have been notable tensions between the prime minister and certain Mauritian journalists, a problem reflected, to a certain extent, in the fact that Mauritius has tumbled from 25th (2007) to 65th (2010) place on the Reporters Without Borders 'Index'. The tensions have ranged from hostile verbal exchanges through the banning of journalists of La Sentinelle Group from ministerial press conferences to an extended withdrawal of government advertisements from the group's publications. Damning reports have emerged from Reporters Without Borders (6 May 2011) about the growing levels of antagonism between the prime minister and certain journalists:

Reporters Without Borders deplores the extremely aggressive comments about the independent media that Prime Minister Navin Ramgoolam made at a meeting of the ruling Alliance of the Future on 1 May, when he accused the daily L'Express and the weekly WeekEnd of just defending the interests of opposition leader Paul Bérenger of the Mauritian Militant Movement. Such comments by the prime minister are creating an appalling climate between the government and media. They are liable to induce most journalists to censor themselves and do Mauritius' image a great deal of harm. The fact that they were made just two days ahead of World Press Freedom Day, on 3 May, is particularly shocking.

There is no doubt that relationships between the media and those in power have often been conflict prone and history is peppered with examples attesting to this. However, a point of no return can be reached very quickly when the nature of conflict becomes vitriolic, abusive and threatening.

\section{Rise in corruption and a growing culture of impunity}

Corruption is the one issue that even the most democratic and open societies have to deal with. According to the latest figures (2010) released by Transparency International, which compiles an annual 'Corruption Perceptions Index', 
Mauritius has a score of 5.4. ${ }^{6}$ A number of observers have actually questioned the usefulness of such a score, which essentially deals with perceptions rather than concrete facts.

Mauritius has both the necessary legislation and the institutional infrastructure to combat corruption. The Prevention of Corruption Act (2002) provides for an Independent Commission Against Corruption (ICAC) to be set up. Unfortunately, since its creation ICAC has been ineffectual as it has been unable to deal with major cases of corruption. A case it is currently investigating concerns the valuation and acquisition by the government of a private clinic which belonged to the son-in-law of the current president of the republic, Sir Aneerood Jugnauth, and the brother-in-law of the current deputy prime minister and minister of finance, Pravin Jugnauth.

What has caused a general public outcry over what is now termed the 'MedPoint Saga' is the lack of transparency surrounding the deal as well as the over-valuation of the property. At the time of writing it was more than six months since ICAC's investigation had begun and no real breakthrough had been achieved. Public opinion was heated over the way public funds were used to line the pockets of those in power. The matter also casts doubt on the independence and autonomy of ICAC in the delivery of its mandate.

Another growing concern is the culture of impunity of those in power. Mauritian politics has, over the years, fine tuned the politics of cronyism whereby once a party or a coalition gets into power it systematically puts friends/family members/political activists in key positions in public and parastatal bodies. Most of the time these purely political nominees do not have the most basic understanding let alone the necessary skills to run these often complex institutions. There have been numerous cases of bad decision-making, mismanagement or wastage of funds, which have cost tax payers a great deal of money, while those who have been the source of the problems have either walked away or, worse, continue to 'manage' key institutions.

Both corruption and impunity, if left unchecked, constitute a direct threat to democracy and a society that is seen to be unequal in terms of access to resources can ultimately implode. Among the elements of the rhetoric of the current government is legislation designed to promote equal opportunity. The much anticipated 'Equal Opportunity Bill', introduced in 2005 and passed by Parliament but still to be promulgated, might help to usher in some form of merit. However, many observers believe that if the Bill ever becomes law it will be yet another white elephant, as the culture of corruption, cronyism and impunity is embedded in Mauritian society.

6 Countries are scored from 10 to 0,10 representing the cleanest and 0 highly corrupt. 


\section{THE CONSOLIDATION OF MAURITIAN DEMOCRACY: THE WAY FORWARD}

One does not wish to be alarmist, but the much vaunted Mauritian melting pot is turning into a boiling pot as mounting evidence shows that socioeconomic disparities are widening, ethnic intolerance is on the rise and the political class is becoming closed, even regressive, in its approach.

These factors could be reversed if the necessary commitment could be mustered from both politicians and the citizenry. Firstly, there is an urgent need to move away from self-glorification (about our leading position on the African continent) and to adopt a more introspective and nuanced assessment of the state of Mauritian democracy.

Over the years Mauritius has done little to improve its democratic score, while countries like Cape Verde, Kenya and Tanzania, to name but a few, have made tremendous efforts to hoist themselves up the democratic ladder. Here it is important to emphasise that democracy is about consolidation, not about maintaining the status quo.

There is an urgent need to renew the Mauritian political class, whether through a process of electoral reform (which has been in abeyance for ten years) or through a more engaged and enlightened citizenry. One hopes that Mauritius is inspired by the Arab awakening, essentially led by the younger generation, who are fed up with ailing, dynastic and closed regimes.

Lastly, Mauritian citizens must play a watchdog role. There is no purpose in voting in each general election and remaining silent between elections. Participation and vertical accountability are two aspects that allow for greater scrutiny of and transparency from those we vote into power.

\section{- REFERENCES}

Ballington, J (ed). 2004 The Implementation of Quotas: African Experiences. International IDEA Publications.

__ \& A Karam (eds). 2005. Women in Parliament: Beyond Numbers. International IDEA Publications.

Barkan, J (ed). 2009. Legislature Power in Emerging African Democracies. Lynne Rienner Publications.

Berman, S. 2010. 'How Democracies Emerge'. In L Diamond, M Plattner \& P Costopoulos (eds). Debates on Democratisation. Baltimore: Johns Hopkins University Press.

Bratton, M. 2010. 'Anchoring the D-word in Africa'. Journal of Democracy 21(4). Baltimore: Johns Hopkins University Press. 
Bunwaree, S \& R Kasenally. 2005. Political Parties in Mauritius. Johannesburg: EISA.

Bunwaree, S. 2010. Governance, Gender and Politics in Mauritius. Mauritius: Editions Le Printemps.

Committee on Evaluation of USAID Democracy Assistance. 2008. Improving Democracy Assistance: Building Knowledge Through Evaluating and Research. Policy and Global Affairs.

Democracy Index. 2010. London: Economic Intelligence Unit Publications.

Diamond, L \& L Morlino (eds). 2005. Assessing the Quality of Democracy. Baltimore: Johns Hopkins University Press.

Diamond, L. 2008. 'The Democracy Rollback'. Foreign Affairs, March/April.

Fish, S \& M Kroening. 2009. The Handbook of National Legislatures: A Global Survey.

New York: Cambridge University Press.

Freedom House. 2010. Washington: Freedom House Publications.

Goodwin-Gill, G S. 2006. Free and Fair Elections. Inter-Parliamentary Union Publications.

Ibrahim, M. 2010. Good Governance Index 2010. London: Mo Ibrahim Foundation Publications.

Independent Daily, The. 2011. 'Ramgoolam promises revelations on May Day', 21

April. Available at: theindependent.mu/2011/04/21

Index of Economic Freedom. 2010. The Heritage Foundation and The Wall Street Journal.

Jahangeer-Chojoo. A. 2010. 'From Minority to Mainstream Politics: The Case of Mauritian Muslims. Journal of Social Sciences 25.

Kadima, D \& R Kasenally. 2006. 'Coalitions and Alliances in Mauritian Politics: The Rise of the Ethnic Factor'. In D Kadima (ed). The Politics of Party Coalitions in Africa. Johannesburg: EISA.

Kasenally, R. 2009. 'Elections in Mauritius'. In D Kadima \& S Booysen (eds). Compendium of Elections in Southern Africa 1989-2009-20 Years of Multiparty Democracy. Johannesburg: EISA.

Little, E \& C Logan. 2009. The Quality of Democracy and Governance in Africa: New Results from Afrobarometer Round 4. Working Paper 108, Afrobarometer Network.

Meade, J. 1961. The Economics and Social Structure of Mauritius: Report to the Government of Mauritius. London: Methuen.

Miles, W F S. 1999. 'The Mauritian Enigma'. Journal of Democracy 10(2).

Naipaul, V S. 1972. The Overcrowded Barracoon and Other Articles. London: André Deutsch.

National Productivity and Competition Council. 2004. Competitiveness Report: What Orientations for Mauritius? Mauritius: NPCC. 
Prevention of Corruption Act 2002. Republic of Mauritius Laws.

Puddington, A. 2011. 'Democracy Under Duress'. Journal of Democracy 22(2).

Reporters Without Borders. 2010. Index. Reporters Without Borders Publications.

—_ 2011 Prime Minister Ramgoolam Launches Blistering Attack on Independent Media. Reporters Without Borders Publications.

Sachs, A, B B Tandon and R Ahnee. 2002. Report of the Commission on Constitutional and Electoral Reform 2001/02.

Srebrnik, H. 2002. 'Full of Sound and Fury: Three Decades of Parliamentary Politics in Mauritius'. Journal of Southern African Studies 28(2). Routledge Publications.

Thomas, S. 1994. How Women Legislate. New York: Oxford University Press.

Transparency International. 2010. Corruption Perception Index. Transparency International Report. 